\title{
The Performance Characteristics and Economic Evaluation of Weaner Rabbits Fed Varying Levels of Sundried False Yam (Icacina Tricantha) Meal
}

\author{
Okosun S. E. ${ }^{1}$, Eguaoje A. S. ${ }^{1} \&$ Obasoyo D. O. ${ }^{1}$ \\ ${ }^{1}$ Department of Animal Science, Faculty of Agriculture, Ambrose Alli University, Ekpoma, Edo State, Nigeria \\ Correspondence: Eguaoje, A. S., Department of Animal Science, Faculty of Agriculture, Ambrose Alli University, \\ Ekpoma, Edo State, Nigeria. Tel: 070-3167-7645, 081-6293-1998.
}

Received: December 11, 2018; Accepted: December 28, 2018; Published: January 18, 2019

The research is financed by (Dr S.E. Okosun).

\begin{abstract}
A seven week feeding trial was conducted to evaluate the growth performance characteristics and economics of production of 15 unsexed weaner rabbits fed varying levels of Sundried false yam (Icacina tricantha) meal. Five treatments diets were formulated with diet 1 containing $100 \%$ maize as control, while in diet 2, 3, 4 and 5 Sundried false yam meal replaced the percentage proportion of maize in diet 1 at 25, 50, 75 and 100\% inclusion level respectively. Rabbits were randomly assigned to the five treatment diets in a complete randomized designed (CRD) with three replicates of one rabbits each. Performance characteristics revealed that final live weight and weekly feed intake were significantly $(\mathrm{P}<0.05)$ influenced with highest value $(2.12 \mathrm{~kg} / \mathrm{rabbit}$ and $407.33 \mathrm{~g} / \mathrm{rabbit})$ recorded from rabbits fed $0 \%$ SDFYM comparable to $(1.98 \mathrm{~kg} / \mathrm{rabbit}$ and $323.33 \mathrm{~g} / \mathrm{rabbits})$ recorded in those fed $50 \%$ SDFYM. Avearage weekly weight gain was also significantly $(\mathrm{P}<0.05)$ influenced with highest value $(197.00 \mathrm{~g} / \mathrm{rabbit})$ from those fed 50\% SDFYM. Feed conversion was lowest and best (1.28) from rabbits fed 25\% SDFYM. Mortality rate was lowest (3.43\%) in rabbits fed 50\% SDFYM. Cost and return analysis revealed that total cost of feed consumed was least (378.24 /rabbits) from those fed 50\% SDFYM and highest in control, cost of feed per kg weight gain and total cost of production were lowest (30.50 and 2178.24 $/$ rabbits) from the rabbits that ate $75 \%$ SDFYM and highest in control. Income and net profit were highest (5000 and $1763.36 \approx$ rabbits). It is concluded from this study that Sundried false yam meal is a valuable substitution for maize up to $50 \%$ in rabbit diets without any adverse effects on the performance characteristics and economic returns of rabbits.
\end{abstract}

Keyword: performance characteristics, weaner rabbits, sundrying, false yam meal

\section{Introduction}

\subsection{Statement of the Problem}

Inadequate poultry and livestock feed supply and nutrition had been identified as the major constraint to poultry and livestock production in Nigeria. This is so because the conventional livestock feedstuffs sources have been very expensive especially in monogastrics diets such as poultry, pigs and rabbits. The search for locally available feedstuffs that can substitute these conventional energy/protein feed ingredient at cheap cost is imperative. The insufficient production of the local feed resources coupled with high cost of importation of foreign feedstuffs for poultry also had tremendous increase in the cost of poultry production in Nigeria (Madubuike and Ekenyem, 2006; Obidinma, 2009).

\subsection{The Importance of the Problem}

The need to boost animal production to produce the much needed protein for the ever increasing human population in the developing countries cannot be over emphasized (FAO, 2007). The production of short cycled animal like rabbit is one of the sure ways to increasing animal protein in most developing countries. Most rabbit breed are typically known and bred specifically for efficient meat production and grows much faster than every other livestocks. Energy is the most expensive part of poultry diet and constitutes up to 60 to $75 \%$ of the total diet, (Okonkwo and Ahaotu, 2014). 


\subsection{Review of Literature}

Recent researchers have discovered that some agro by-products such as cassava pulp seviate, maize offal, wheat offal, cassava, yam, cocoyam and plantain peels, some plant leaves and animal wastes which hitherto were discarded as waste are now used as livestock feed to partially or totally replace a proportion of conventional energy and protein sources such as maize, sorghum, wheat, oat, soybean and groundnut whose prices have gone very high, (Obidinma, 2009; Ani and Omeje, 2008). Okosun and Eguaoje, (2017) also reported that Cassava grit at 66.6\% level of inclusion with 5\% moringa leaf meal supplementation resulted in better biological performance in cockerel chickens. An example of unconventional root crop with great potential as livestock feed is false yam (Icacina tricantha), a small perennial shrub that is drought resistant. The plant produces erect leaf shoots from a large underground fleshly tuber. It belongs to the family of Icacinaceae. It is indigenous to West and Central Africa. No pest and diseases have been reported (Kay, 1987). People truly enjoy the fruit as well as the seed, which represent a permanent, reliable and very tasty fruit. The tubers which resemble large turnips or beet roots is such a great source of emergency moisture and feed energy to the plant that it can survive at least four years without rain. Thus, as long as false yam is around, food is always available for people. False yam has been reported to contain hydrocyanic acid, phytic acid and oxalic acid the same bitter principle as cassava, a global staple (Antai and Nkwelang,1999). It is yet to gain recognition and popularity as a food crop. Processing it into stable flour and analyzing its antinutritional composition will make the crop known to a greater majority of the people as a food crop and feed ingredients for livestocks Information on the nutrient level of Icacina tricantha has earlier been investigated by (Umoh and Iwe, 2014; Okosun et al., 2018) and their findings revealed that this root tuber have a potential in terms of energy and protein to substitute for maize weight for weight.

\subsection{Objective of the Study}

The aim of this study is to investigate the effect of feeding varying levels of sundried False yam (Icacina tricantha) meal on the growth performance and economics of producing weaner rabbits.

\section{Materials and Methods}

\subsection{Location and Duration of the Study}

The experiment was carried out in the Department of Animal Science, livestock section Rabbitary Unit of the Teaching and Research Farm, Ambrose Alli University, Ekpoma for period of 6 weeks.

\subsection{Sourcing and Processing of Raw Materials}

Fresh tubers of Icacina tricantha was collected from Ambrose Alli University Ekpoma main campus in Esan West Local government area of Edo State, Nigeria. The tubers were washed, chopped into small pieces and spread on the polythene mat placed under the sun for optimum drying. All the chopped and processed tubers were grind into a fine powder to pass through a $2 \mathrm{~mm}$ mesh-sieve until ready to use.

\subsection{Chemical Analysis of the Raw Material}

The moisture content, ash, crude fibre and crude fat, were determined using the method described by AOAC (1990). The crude protein was also determined by Kjeldahl method. The energy value was determined using an Adiabatic Oxygen Bomb calorimeter (12149 Adiabatic calorimeter, PARR instrument Co. Illinois USA.

Table 1. Proximate composition of sundried false yam and maize

\begin{tabular}{lll}
\hline Parameters & SFYM & Maize \\
\hline Dry matter & 9.49 & 10.46 \\
Crude protein & 6.03 & 8.90 \\
Crude fibre & 1.31 & 1.38 \\
Ether extract & 1.77 & 4.47 \\
Crude ash & 2.34 & 1.49 \\
NFE & 79.06 & 73.03 \\
Carbohydrate & 88.53 & 82.62 \\
\hline
\end{tabular}

\subsection{Design and Management of Experimental Animals}

A total of 15 mixed bred rabbits of average same weight were purchased from the Teaching and Research farm Benson Idahosa University, Benin city, Edo State for the experiment. The rabbits were kept under a standard temperature $\left(25^{\circ} \mathrm{C}\right)$, relative humidity $(45 \%-55 \%)$, dark/light cycle (12 hours), and were fed with the commercial 
diet supplemented with Elephant grass (Pennisetum purpeurum) for 4 weeks acclimatization period and will had free access to clean water ad libitum. The rabbits that were randomly allotted in a completely randomized design (CRD) to five dietary treatments with treatment 1 being the control i.e (100\% maize), treatment $2,3,4$ and 5 formulated to have a replacement level of maize with Sun dried (Icacina tricantha) meal at 25, 50, 75 and 100\% respectively and were replicated three times across the treatments. All the diets ( 1 to 5$)$ were formulated to be isonitrogenous (16\%) and isocaloric $(2600 \mathrm{ME} \mathrm{Kcal} / \mathrm{kg})$ as reflected in Tables 2 . The study lasted seven weeks during which growth parameters were collected as depicted in table 3

Table 2. Gross composition of Experimental Rabbit Diets

\begin{tabular}{llllll}
\hline \multicolumn{5}{l}{ Inclusion level of SFYM (\%) } \\
\hline & 0 & 25 & 50 & 75 & 100 \\
\hline & Diets & & & & \\
\hline Ingredients & 1 & 2 & 3 & 4 & 5 \\
Maize & 56.12 & 42.09 & 28.06 & 14.03 & 0.00 \\
SFYM & 0.00 & 14.03 & 28.06 & 24.09 & 56.12 \\
Soya bean meal & 15.96 & 16.38 & 16.76 & 17.02 & 18.02 \\
Wheat offal & 20.00 & 20.00 & 20.00 & 20.00 & 20.00 \\
Bone meal & 2.00 & 2.00 & 2.00 & 2.00 & 2.00 \\
Lime stone & 5.28 & 4.86 & 4.44 & 4.22 & 4.22 \\
Salt & 0.34 & 0.34 & 0.34 & 0.34 & 0.34 \\
Premix & 0.30 & 0.30 & 0.30 & 0.30 & 0.30 \\
\hline Total & 100.00 & 100.00 & 100.00 & 100.00 & 100.00 \\
\hline Calculated analysis & & & & & \\
Crude protein & 16.00 & 16.03 & 16.05 & 16.02 & 16.00 \\
Crude fibre & 3.28 & 3.81 & 3.79 & 3.78 & 3.77 \\
Ether extract & 3.25 & 3.02 & 2.79 & 2.56 & 2.88 \\
Calcium & 2.00 & 1.88 & 1.75 & 1.62 & 1.70 \\
Ash & 3.28 & 3.81 & 3.79 & 3.78 & 3.77 \\
ME(kcal/kg) & 2559.00 & 2620.00 & 2642.00 & 2663.00 & 2673.00 \\
\hline
\end{tabular}

\subsection{Performance Study}

During the feeding trial, weekly feed consumption and weight changes were recorded where weight gain, feed conversion ratio and protein efficiency ratio were estimated. Daily feed intake was determined by subtracting the weight of left over feed from the initial weight of feed supplied.

i.e. $\quad$ Feed intake $=$ Feed given - Left over of feed

Weekly weight gain was determined as the difference between the weight at the beginning of the week and the weight at the end of each week.

Feed conversion ratio was estimated as the ratio of the feed intake to that of the weight gain

i.e. $\quad$ Feed conversion ratio $=\underline{\text { Feed intake }(\mathrm{g})}$

$$
\text { Weight gain }(\mathrm{g})
$$

Protein efficiency ratio (PER) was determined as the ratio consumed to weight gained.

i.e. $P E R=$ Weight gain $(g)$

Protein consumed $(\mathrm{g})$

\subsection{Economics of Production}

The prices of the feed ingredients prevailing in the market as at the time of the experiments was used to estimate the total cost of producing each experimental ration. This was used to estimate the cost per $\mathrm{kg}$, total cost of feed consumed per rabbit ( $\mathrm{N}$ ) and cost of feed per kg weight gained ( $\mathrm{N}$ )

\subsection{Statistical Analysis}

All the data collected were subjected to analysis of variance (ANOVA) and difference between means and treatments determined using Duncan's multiple range test (DMRT) at 5\% level of probability. All statistical procedures were according to Steel and Torrie, (1990) with the aid of SPSS 20 package. 


\section{Results}

\subsection{Performance Studies}

The performance parameters of weaner rabbits as affected by the treatment diets are shown in (Table 3). The treatment diets significantly $(\mathrm{P}<0.05)$ affected the average final live weight, average weekly feed intake and average weekly weight gain. The average initial weights and feed conversion ratio of rabbits were statistically $(\mathrm{P}>0.05)$ similar. Average final live weight was significantly higher among rabbits place on the control diet with a mean value of $2.12 \mathrm{~kg} / \mathrm{rabbit}$, followed by comparable mean value of $1.98 \mathrm{~kg} / \mathrm{rabbit}$ from those fed the $50 \%$ SDFYM, while lowest mean value of $1.49 \mathrm{~kg} /$ rabbit was from rabbits placed on $25 \%$ SDFYM. Average weekly feed intake was highest $(\mathrm{P}<0.05)$ among rabbits fed the control diet with an average value of $407.33 \mathrm{~g} / \mathrm{rabbits}$, followed by comparable value of $323.33 \mathrm{~g} /$ rabbit in those fed 50\% SDFYM, while lowest values of $175 \mathrm{~g} / \mathrm{rabbit}$ in those placed on $100 \%$ SDFYM. Average weekly weight gain was significantly $(\mathrm{P}<0.05)$ highest in rabbits maintained on $50 \%$ SDFYM with a mean value of $197.00 \mathrm{~g} / \mathrm{rabbit}$ comparable to $180.00 \mathrm{~g} / \mathrm{rabbit}$ in rabbits fed $25 \%$ SDFYM, followed by $174.00 \mathrm{~g} /$ rabbit in those fed the control. Similar values of 108.67 and $85.00 \mathrm{~g} / \mathrm{rabbit}$ were recorded in those placed on diets 4 and 5 respectively. Mortality rate was highest $(10.00 \%)$ from rabbits fed $100 \%$ SDFYM, followed by those rabbits placed on 20 and $75 \%$ SDFYM replacement of maize. Those fed $50 \%$ SDFYM had mortality value of $3.34 \%$ while no mortality was recorded from rabbits fed the control diets.

Table 3. Performance characteristics of weaner rabbits fed the dietary treatments

\begin{tabular}{lllllll}
\hline & \multicolumn{7}{c}{ Inclusion level of SFYM (\%) } \\
\hline & 0 & 25 & 50 & 75 & 100 \\
\hline Parameters & 1 & 2 & 3 & 4 & 5 & SEM \pm \\
Initial weight $(\mathrm{kg} / \mathrm{r})$ & 0.97 & 1.13 & 1.10 & 0.93 & 1.10 & 0.39 \\
Final live weight $(\mathrm{kg} / \mathrm{r})$ & $2.12^{\mathrm{a}}$ & $1.49^{\mathrm{c}}$ & $1.98^{\mathrm{a}}$ & $1.59^{\mathrm{b}}$ & $1.62^{\mathrm{b}}$ & 0.06 \\
Weekly feed intake $(\mathrm{g} / \mathrm{r})$ & $407.33^{\mathrm{a}}$ & $288.67^{\mathrm{b}}$ & $323.33^{\mathrm{ab}}$ & $202.00^{\mathrm{c}}$ & $175.00^{\mathrm{c}}$ & 1.00 \\
Weekly feed intake $(\mathrm{g} / \mathrm{r})$ & $174.00^{\mathrm{b}}$ & $180.00^{\mathrm{ab}}$ & $197.00^{\mathrm{a}}$ & $108.67^{\mathrm{c}}$ & $85.00^{\mathrm{c}}$ & 0.06 \\
Feed conversion ratio & 2.17 & 1.28 & 1.86 & 1.86 & 1.90 & 0.11 \\
Mortality (\%) & 0.00 & 6.67 & 3.34 & 6.67 & 10.00 & \\
\hline
\end{tabular}

$a b c$ : means in the same row with varying super script differ significantly $(P<0.05)$.

SEM+: standard error of mean; SFYM. Sundried false yam meal.

Table 4. Cost and return analysis of rabbits fed the treatment diets

\begin{tabular}{llllll}
\hline & \multicolumn{5}{c}{ Inclusion level of SFYM (\%) } \\
\hline & 0 & 25 & 50 & 75 & 100 \\
\hline & & \multicolumn{5}{c}{ Diets } \\
\hline Parameters & 1 & 2 & 3 & 4 & 5 \\
Cost of rabbits ( $\#$ /rabbits) & 1500.00 & 1500.00 & 1500.00 & 1500.00 & 1500.00 \\
Cost of feed consumed( $($ ) & 1740.00 & 1126.38 & 1136.64 & 378.24 & 487.26 \\
Cost of feed/Kg & 119.07 & 108.39 & 97.65 & 52.01 & 77.35 \\
Cost of feed consumed (\#/rabbits) & 290.05 & 187.73 & 189.44 & 63.04 & 81.21 \\
Total cost of production (\#/rabbit) & 85.20 & 64.26 & 53.10 & 30.50 & 34.33 \\
Income & 5000.00 & 3500.00 & 5000.00 & 4000.00 & 4000.00 \\
Net profit & 1459.70 & 873.62 & 1763.36 & 1521.76 & 1412.74 \\
\hline
\end{tabular}

\subsection{Economics of Production}

Table 4. reflects the cost and returns analysis of feeding sundried false yam meal as a partial replacement for maize in weaner rabbits. Cost of weaner rabbits were $\$ 1500.00$, Total cost of feed consumed was highest in dietary treatment $1(\$ 1,740.00)$, followed by Diet $3(\$ 1,136.64)$ and least total cost of ( $\$ 378.24)$ from rabbits that consumed diet 4. Cost of feed consumed ( $\mathrm{N} /$ rabbit) was highest in weaner arbbits maintained on the control diet ( $\$ 290.05$ ), followed by $\$ 189.44$ in rabbits placed on 50\% SDFYM, followed by $\$ 187.73$ in those fed 25\% SDFYM while least cost of feed consume ( $\$ 63.04$ ) was observed in rabbits fed 75\% SDFYM. The least cost of feed per kg weight gain was recorded in rabbits fed dietary treatment 4 ( $\$ 30.50)$, followed by diet 5 ( $\$ 34.33$ ) 
while highest cost of ( $\$ 85.20$ ) was recorded in rabbits placed on diet 1. Total cost of production was highest in rabbits fed treatment diet 1 ( $\$ 3540.30$ ), followed by diet 3 ( $\$ 2963.64$ ), followed by among those that ate diet 2 (\$2962.38). Diet 5 recorded total production cost of (\$2287.26) and least cost of production of (\$2178.24) was obtained in rabbits fed treatment diet 4 . Revenue was highest among rabbits that ate the control diet with a price of ( $\$ 5000.00)$, followed by similar income of $(\$ 5,000.00)$ realised from rabbits that ate diets 3 while lowest income of ( $\$ 3500.00$ ) were realised from those fed diet 2. Net profit was least in diet 2 ( $\$ 873.62$ ), followed by diet 5 ( $\$ 1412.74)$, diet 1 ( $\$ 1459.70)$, and by ( $\$ 1521.76)$ in diet 4 while highest income was realised in rabbits fed dietary diet 3 ( $\$ 1763.36)$.

\section{Discussion}

\subsection{Performance Characteristics}

The significant $(\mathrm{P}<0.05)$ increase in the average final live weight of the rabbits fed the control comparable to those fed $50 \%$ sundried false yam meal (SDFYM) which was brought about by the significant increase in weekly feed consumption could be adduced to the nutrient availability and density which eventually translated to the improvement in growth rate of the weaner rabbits. It also indicate that sundried false yam meal at $50 \%$ level of inclusion was effectively utilized by the rabbits. This lend support from the report of Ansar et al., (2012) who reported a significant $(\mathrm{P}<0.05)$ variation in the weight gain and final live weight of weaner rabbits fed false yam leaves. The significant $(\mathrm{P}<0.05)$ variation in the feed intake value with highest mean recorded in control similar to those on 50\% SDFYM could be ascribed to the high level of palatability and Metabolizable energy in the diet as rabbits are known to satisfy their energy requirement (Atteh, 2004) and Icacina thricantha (False yam) as reported by Sunday et al.,(2016) is known to contain a very high level of carbohydrate. The comparable ( $>0.05)$ values recorded in the feed conversion ratio among rabbits fed the dietary treatments is a pointer to the fact that the inclusion of the basal diet at the various level of inclusion improves the standard of the quality of the feed. This observation is in Tandem with that of Nworgu et al., (2000) and Oduguwa et al., (2004). This finding however negates the report of Ansar et al., (2011) who observed a significant variation in the feed to gain ratio value of weaner rabbits fed false yam leaf meal. However, the higher mortality rate recorded among rabbits fed $100 \%$ false yam is traceable to the fact that the high inclusion would have aided the intake of more of the anti nutrients present in false yam which would have hampered the health status of the animal and eventually led to their death. Sunday et al., (2016) in their research on the proximate analysis and mineral element composition of false yam (Icacina trichantha) tuber and oyster mushroom (Pleurotus ostreatus) reported that false yam contain anti nutrients like phytic acid, tannin, cyanide and oxalate so if consumed in high quantity could be detrimental to the health of the animal and could lead to death.

\subsection{Cost and Return Analysis of Rabbits Fed Treatment Diet}

The least cost of feed consumed and cost of feed per kilogram weight gain recorded among rabbits fed diet $75 \%$ sundried false yam meal (SDFYM) and highest in the control could be as a result of next to nothing cost of false yam (SDFYM) apart from the labour associated with harvesting and processing compared to expensive maize used in formulating the control diet. This observation was supported by the findings of Bello et al. (2011) on reduction in the cost of feed, cost of feed $/ \mathrm{kg}$ weight gain, cost of production and improvement in the profit margin in broiler chickens fed palm kernel meal in their diets. The least cost of production recorded in rabbits fed diet 4 could be due to the reduced feed intake and low price of false yam meal. This lend support from the report of Nworgwu et al. (2000) who stated that there is need for dietary incorporation of unconventional feed ingredient as alternative, noncompetitive, readily available and cheap ingredients so as to reduce the cost of production and in the long run increase profit margin. The highest revenue and net profit recorded among rabbitss fed 50\% SDFYM compare to control was a pointer to the fact that the inclusion of sundried false yam meal at $50 \%$ level reduced cost of production and thus translated to higher profit margin. Zahari and Alimon (2006) had earlier reported improvement in the feed efficiency through the accelerated use of local feed stuff in other to reduce high production cost thereby increasing profit.

\subsection{Conclusion}

It is therefore concluded from this study that sundried false yam meal could be a valuable replacement for maize up to $50 \%$ in rabbit diets without any deleterious effects on the performance and cost effectiveness of rabbit production.

\section{References}

Ani, A. O., \& Omeje, O. D. (2007). Response of broiler finishers to graded levels of raw bambara nut (Vigna subterranea (L) Verdc) waste and supplementary enzyme. Tropical Journal of Animal Science, 10(1-2), 281- 
288.

Antai S. P., \& Nkwelang, G. (1998). Reduction of some toxicants in Icacina mannii by fermentation with Saccharomyces cerevisiae. Plant Foods for Human Nutr., 53, 103-111. https://doi.org/10.1023/A:1008060029175

Chemists, A. O. A. (1990). Official Methods of Analysis. $15^{\text {th }}$ ed. Association of Official Analytical Chemists, Washington D.C.

Esonu, B. O., Emenalom, O. O., Udedibie, A. B. I., Herbert, U., Ekpor, C. F., Okolie, I. C., \& Iheukwumere, F. C. (2001). Performance and bloodchemistryof weaner pigs fed raw mucuna (velvetbean). Trop. Anim. Prod. Invest., 4, 49-54.

Fagbemi, T., Eleyimi, A., Atum, H., \& Akpambang, O. (2005). Nutritional composition of fermented fluted pumpkin (Telfairiaoccidentalis)seed for production of "Ogiri Ugu" fermented foods and beverages: General 2005 IFT Annual Meeting, New Orleans, Louisiana.

FAO. (2014). (Food and Agriculture Organization of the United Nations). Food Outlook. Biannual report on global food markets.

Iwe, M. O. (2003). The Science and Technology of Soybean. Rojoint Communication Services Ltd. Enugu, Nigeria, 70-97, 149.

Kay, D. E. (revised by Gooding, E.G.B.) (1987). Crop and Product Digest No. 2 - Root Crops. 2nd edn. London: Tropical Devt. And Research Inst., 91-93.

Madubuike, F. N., \& Ekenyem, B. U. (2006). Haematologyandserum Biochemistry characteristics of Broilerchicksfed varying Dietary levels of ipomoea asarifolia leaf meal. Int. J. Poult Sci., 5, 9-12. https://doi.org/10.3923/ijps.2006.9.12

National Research Council of the National Academic Press (NRCNAP). (2008). Lost crops of Africa: fruits, Vol. II ICACINA. Retrieved from http://www.books.nap.edu/open book.php.23/07/2008.

Obidinma, V. N. (2009). Brewers' spent grain as energy source in finisher broiler birds and laying hen production. $\mathrm{Ph} . \mathrm{D}$. Thesis, Imo state University, Owerri, Nigeria.

Okonkwo, V. N., \& Ahaotu, E. O. (2014). Effects of cassava pulpseviate meal on heamatological indices of finisher broiler birds. World J. of Agricultural Science, 2(6), 142-145 August 2014.

Okosun, S. E., \& Eguaoje, S. A. (2017). Growth Performance, Carcass Response And Cost Benefit Analysis of Cockerel Fed Graded Levels Of Cassava (Manihot esculenta) Grit Supplemented With Moringa (Moringa Oleifera) Leaf Meal. Animal Research International, 14(1), 2619-2628.

Omeje, S. S. I. ( 2001). Heterosis for body weight in native by exotic inbred chicken crosses. Tropical Journal of Animal Science, 4(1), 1-14.

SAS. (1999). SAS Users Guide Statistics. SAS Institute Cary, North Carolima, USA.

Steel, R. G. D., \& Torrie, J. H. (1990). Principle and procedure of statistics. A Biometrical Approach $3^{\text {rd }}$ Edition. MacGraw Hill Book Co. New York.

Udedibie, A. B. I., Anyaegbu, B. C., Onyechekwa, G. C., \& Egbuokporo, O. R. (2004). Effect of feeding level of fermented and unfermented cassava tuber meals on performance of broilers. NJAP, 31, 211

Umoh, E. O. L., \& Iwe, M. O. (2014). Effects of Processing on the Nutrient Composition of False Yam (Icacina trichantha) Flour. Official Journal of Nigerian Institute of Food Science and Technology. NIFOJ, 32(2), 1-7.

\section{Copyrights}

Copyright for this article is retained by the author(s), with first publication rights granted to the journal.

This is an open-access article distributed under the terms and conditions of the Creative Commons Attribution license (http://creativecommons.org/licenses/by/4.0/). 